\title{
PENGARUH RASIO LIKUIDITAS, SOLVABILITAS, PROFITABILITAS TERHADAP HARGA SAHAM SUBSEKTOR PERKEBUNAN YANG TERDAFTAR DI BURSA EFEK INDONESIA
}

\section{THE EFFECT OF LIQUIDITY, SOLVABILITY, PROFITABILITY RATIO ON THE PRICE OF PLANTATION SUBSECTORS LISTED IN INDONESIA STOCK EXCHANGE}

\author{
Eka Sholeha Thea ${ }^{1}$, Hari Sulistyo ${ }^{2}$ \\ Universitas Singaperbangsa Karawang,Indonesia ${ }^{1,2}$ \\ ekasholehathea646@,gmail.com ${ }^{1}$
}

\begin{abstract}
ABSTRAK
Harga Saham adalah cerminan keberhasilan pengelolaan perusahaan. Harga saham yang tinggi akan memberikan keuntungan, yaitu berupa capital gain dan citra yang lebih baik bagi perusahaan sehingga akan membuat para investor tertarik untuk berinvestasi di perusahaan tersebut. Penelitian ini bertujuan untuk mengetahui apakah terdapat pengaruh antara Likuiditas, Solvabilitas dan Profitabilitas terhadap Harga Saham baik secara parsial maupun simultan. Sampel penelitian yang diambil yaitu 11 perusahaan dari total 19 Perusahaan Subsektor Perkebunan Yang Terdaftar Di Bursa Efek Indonesia Tahun 2016-2018 dengan teknik sampling yang digunakan adalah teknik purposive sampling. Metode penelitian yang digunakan yaitu deskriptif dan verifikatif, dimana deskriptif menggunakan statitik deskriptif dan verifikatif menggunakan analisis regresi linear berganda dan koefisien determinasi. Hasil penelitian ini secara parsial Current Ratio tidak berpengaruh terhadap Harga Saham, Debt To Equity Ratio berpengaruh negatif terhadap Harga Saham dan Return On Equity berpengaruh negatif terhadap Harga Saham.
\end{abstract}

Kata Kunci: Harga Saham, Likuiditas, Solvabilitas, Profitabilitas

\section{ABSTRACT}

Share Price is a reflection of the successful management of the company. A high share price will provide benefits, namely in the form of capital gains and a better image for the company so that it will attract investors to invest in the company. This study aims to determine whether there is an influence between liquidity, solvency and profitability on stock prices either partially or simultaneously. The research sample taken was 11 companies from a total of 19 plantation subsector companies that were listed on the Indonesia Stock Exchange in 2016-2018 with the sampling technique used was purposive sampling technique. The research method used is descriptive and verification, where descriptive uses descriptive statistics and verification uses multiple linear regression analysis and the coefficient of determination. The results of this study partially Current Ratio has no effect on stock prices, Debt to Equity Ratio has a negative effect on stock prices and Return on Equity has negative effects on stock prices.

Keywords: Stock Price, Liquidity, Solvency, Profitability 


\section{PENDAHULUAN}

Indonesia adalah suatu negara yang memiliki sumber daya alam yang sangat melimpah. Indonesia juga dikenal dengan sebutan negara agraris karena sebagian besar mata pencaharian masyarakat Indonesia adalah bertani atau berkebun, hampir dari setengah perekonomian Indonesia disumbangkan dari kegiatan pertanian dan perkebunan. Indonesia pada tahun 2016, mampu menghasilkan 36.000 .000 ton dan sebanyak 25,1 ton diekspor ke luar negeri. Negara Indonesia sendiri bisa dikatakan sebagai negara yang mengeuasai lalu lintas perdagangan minyak kelapa sawit sebesar 35\% kebutuhan dunia pada tahun 2012.

Rasio Keuangan adalah salah satu alat analisis keuangan yang digunakan oleh perusahaan dalam menilai kinerja perusahaannya dengan adanya rasio keuangan maka pihak manajemen perusahaan, investor dan kreditur akan lebih mudah dalam mengetahui permasalahan keuangan dan kelemahan keuangan perusahaan, dan mempermudah dalam pengambilan keputusan para investor untuk menanamkan saham. Menurut Indra \& Pardinan (2014) yaitu rasio keuangan adalah bagian dari analisi bisnis atas prospek dan risiko perusahaan untuk kepentingan pengambilan keputusan dengan menstrukturkan tugas analisis melalui evaluasi atas bisnis lingkungan perusahaan, strateginya, serta posisi dan kinerja keuangan.

Harga Saham adalah cerminan keberhasilan pengelolaan perusahaan. Harga saham yang tinggi akan memberikan keuntungan, yaitu berupa capital gain dan citra yang lebih baik bagi perusahaan sehingga akan membuat para investor tertarik untuk berinvestasi di perusahaan tersebut. Menurut Endah \& Rishi (2017) "harga saham merupakan salah satu indikator keberhasilan pengelolaan perusahaan, jika harga saham suatu perusahaan selalu mengalami kenaikan, maka investor atau calon investor menilai bahwa perusahaan berhasil dalam mengelola usahanya. Kepercayaan investor atau calon investor sangat bermanfaat bagi emiten, karena semakin banyak orang yang percaya terhadap emiten maka keinginan untuk berinvestasi pada emiten semakin kuat.

Semakin banyak permintaan terhadap saham suatu emiten maka dapat menaikan harga saham tersebut. Jika harga saham yang tinggi dapat dipertahankan maka kepercayaan investor atau calon investor terhadap emiten juga semakin tinggi dan hal ini dapat menaikan nilai emiten. Sebaliknya, jika harga saham mengalami penurunan terus-menurus berarti dapat menurunkan nilai emiten dimata investor" (Frendy, et.al, 2015)

Berdasarkan latar belakang tersebut dan berdasarkan hasil penelitian terdahulu serta untuk mengetahui informasi manakah yang lebih akurat antara pengaruh Current Ratio (CR), Debt to Equity Ratio (DER), Return On Equity Ratio (ROE) terhadap harga saham, Manakah yang lebih mempengaruhi dan yang tidak mempengaruhi.

\section{METODE PENELITIAN}

Metode yang akan digunakan dalam penelitian ini adalah metode deskriptif dan verifikatif. Variabel dalam penelitian ini terdiri dari variabel dependen yaitu harga saham sedangkan variabel independen adalah current ratio, debt to equity ratio, dan return on equity ratio. Populasi dalam penelitian ini adalah perusahaan subsektor perkebunan yang terdaftar di Bursa Efek Indonesia 2016 sampai dengan tahun 2018. Sampel dalam penelitian ini sebanyak 11 perusahaan subsektor perkebunan. Penentuan jumlah data menggunakan 
populasi dalam penelitian ini yaitu laporan keuangan tahunan perusahaan subsektor perkebunan dengan jumlah 33 data.

\section{HASIL DAN PEMBAHASAN Uji Normalitas}

Hasil pengujian normalitas residual menunjukan sudah berdistribusi normal, yang ditunjukan nilai signifikansi pengujian Kolmogrov-smirnov tersebut lebih besar dari 0,05 . Hal ini berarti data residual terdistribusi normal.

\section{Uji Multikolinieritas}

Pada uji multikolinieritas nilai tolerance variabel Current Ratio sebesar 0,635, nilai Debt To Equity Ratio sebesar 0,674 dan Return On Equity Ratio sebesar 0,799. Artinya nilai tolerance masing-masing variabel bebas lebih besar dari 0,1. Sementara itu nilai VIF Current Ratio sebesar 1,574, Debt To Equity Ratio sebesar 1,484 dan Return On Equity Ratio sebesar 1,252. Sehingga dapat disimpulkan bahwa analisis linier berganda di dalam penelitian ini bebas dari multikolinearitas.

\section{Uji Autokolersi}

Hasil Uji Autokorelasi pada model summary, terlihat nilai Durbin Watson sebesar 1.861. Yang berarti nilai yang dihasilkan $\mathrm{du}<\mathrm{d}<4$-du $(1,729<$ $1,861<4-1,729)$. Dapat disimpulkan bahwa model regresi ini bebas autokorelasi.

\section{Uji Heteroskedastisitas}

Pada uji heteroskedestisitas nilai Sig variabel Current Ratio sebesar 0,743 Debt To Equity Ratio sebesar 0,170 dan Return On Equity Ratio sebesar 0,125. Artinya nilai Sig dari masing-masing variabel bebas lebih besar dari 0,05. Sehingga dapat disimpulkan bahwa analisis regresi di dalam penelitian ini bebas dari gejala heteroskedastisitas.

\section{Analisis Regresi Linier Berganda}

Tabel 1. Hasil Analisis Linier Berganda

Unstandardized

Coefficients

\begin{tabular}{lccc} 
& \multicolumn{3}{c}{ Std. } \\
Model & B & Error & Beta \\
\hline 1 (Constant) & 16.501 & 68.395 & \\
\hline CR & -1.145 & 12.275 & -.021 \\
\hline DER & -13.541 & 10.523 & -.279 \\
\hline ROE & -23.310 & 39.918 & -.118
\end{tabular}

Sumber: Output SPSS (2020)

Berdasarkan analisis regresi linier berganda bahwa nilai konstanta sebesar 16,501, koefisien regresi Current Ratio sebesar -1,145, Debt To Equity Ratio sebesar -13,541 dan koefisien Return On Equity Ratio sebsar -23,310. Dari data tersebut, maka didapat persamaan regresi sebagai berikut, $\mathrm{Y}=16,501+(-1,145) \mathrm{X} 1$ $+(-13,541) \mathrm{X} 2+(-23,310) \mathrm{X} 3+\mathrm{e}$.

\section{Hasil Koefisien Determinasi}

Tabel 2. Hasil Analisis Koefisien Determinasi

\begin{tabular}{ccccc}
\hline & \multicolumn{2}{c}{ R } & Adjusted & Durbin- \\
Model & $\mathrm{R}$ & Square & R Square & Watson \\
\hline 1 & $.575^{\mathrm{a}}$ & .761 & .623 & 8.31829 \\
\hline \multicolumn{4}{c}{ Sumber: Output SPSS (2020) }
\end{tabular}

Berdasarkan hasil perhitungan tabel diatas, dapat diketahui bahwa nilai yang di dapat untuk R Square sebesar 0,761 atau sebesar 76,1\%. Hal ini menunjukan bahwa variabel yang diteliti yaitu Current Ratio, Debt To Equity Ratio dan Return On Equity berpengaruh sebesar 76,1\% terhadap Harga Saham. Sedangkan sisanya sebesar $22,9 \%$ dipengaruhi oleh variabel yang tidak di teliti dalam penelitian ini. 


\section{Uji Parsial (Uji t)}

Tabel 3. Hasil Uji Hipoteses Secara Parsial

\begin{tabular}{|c|c|c|c|c|c|}
\hline \multirow[b]{2}{*}{ Model } & \multicolumn{2}{|c|}{$\begin{array}{l}\text { Unstandardized } \\
\text { Coefficients }\end{array}$} & \multirow[b]{2}{*}{ Beta } & \multirow[t]{2}{*}{$\mathrm{t}$} & \multirow[t]{2}{*}{ Sig. } \\
\hline & B & $\begin{array}{c}\text { Std. } \\
\text { Error }\end{array}$ & & & \\
\hline 1 (Constant) & 16.501 & 68.395 & & 2.413 & .022 \\
\hline CR & -1.145 & 12.275 & -.021 & -.093 & .062 \\
\hline DER & -13.541 & 10.523 & -.279 & -1.287 & .004 \\
\hline ROE & -23.310 & 39.918 & -.118 & -.584 & .009 \\
\hline
\end{tabular}

Sumber: Output SPSS (2020)

Berdarkan hasil perhitungan tabel di atas, dapat terlihat nilai significance thitung pada setiap variabel. Dengan hasil ttabel pada $\mathrm{df}=\mathrm{n}-\mathrm{k}-1 \quad(33-3-1)=29$ dengan tingkat significance $0,05 \%$ diperoleh nilai ttabel sebesar 2,042. kesimpulan tidak ditolak atau ditolak yang didapat dari hasil pengujian pengaruh Harga Saham yang di proksikan menggunakan Current Ratio, Debt To Equity Ratio dan Return On Equity Terhadap Harga Saham pada Perusahaan Subsektor Perkebunan Yang Terdaftar Di Bursa Efek Indonesia Tahun 2016-2018

\section{Current Ratio terhadap Harga Saham}

Berdasarkan hasil pengujian pengaruh Current Ratio terhadap Harga Saham diperoleh thitung $<$ ttabel yakni $0,093<2,042$ dan nilai Signifikan 0,062 $>0,05$. Sehingga dapat disimpulkan $\mathrm{H} 1$ ditolak dan H0 ditolak. Dengan demikian variabel Current Ratio tidak berpengaruh terhadap Harga Saham.

\section{Pengaruh Debt to Equity Ratio Terhadap Harga Saham}

Berdasarkan hasil pengujian pengaruh Debt To Equity Ratio terhadap Harga Saham diperoleh nilai thitung < ttabel yakni $-1,287<2,042$ dan nilai signifikan $0,004<0,05$. Sehingga dapat disimpulkan $\mathrm{H} 2$ ditolak dan $\mathrm{H} 0$ diterima. dengan demikian variabel Debt To Equity Ratio berpengauh negatif terhadap Harga Saham.

\section{Pengaruh Return On Equity Ratio terhadap Harga Saham}

Berdasarkan hasil pengujian pengaruh Return On Equity Ratio terhadap Harga Saham diperoleh nilai thitung $<$ ttabel yakni $-2,584>2,042$ dan nilai signifikan $0,009<0,05$. Sehingga dapat disimpulkan $\mathrm{H} 3$ diterima dan $\mathrm{H} 0$ diterima. dengan demikian variabel Return On Equity Ratio berpengauh positif terhadap Harga Saham.

\section{Uji Simultan (Uji f)}

Pengujian ini menggunakan statistik uji f. Hasil pengujian secara simultan dengan bantuan software SPSS yaitu sebagai berikut :

Tabel 4. Hasil Uji Hipotesis Secara Bersamasama (Uji f)

\begin{tabular}{lrrrrr}
\hline Model & df & $\begin{array}{c}\text { Mean } \\
\text { Square }\end{array}$ & F & Sig. \\
\hline \multirow{2}{*}{1} & Regression & 3 & 548.601 & .793 & $.02^{\text {b }}$ \\
\cline { 2 - 6 } & Residual & 29 & 69.994 & & \\
\cline { 2 - 5 } & Total & 32 & & & \\
\hline
\end{tabular}

Sumber: Output SPSS (2020)

Berdasarkan hasil pengujian di atas, dapat diketahui nilai fhitung sebesar 0,793 . Adapun nilai ftabel pada tingkat signifikansi 5\% dan derajat kebebasan $\mathrm{df}=\mathrm{n}-\mathrm{k}(33-3)=30$ dimana $\mathrm{n}$ merupakan jumlah sampel dan $\mathrm{k}$ variabel independen maka ftabel didapat sebesar 2,92.

Berdasarkan pengujian secara simultan pengaruh Current Ratio, Debt To Equity Ratio dan Return On Equity Ratio terhadap Harga Saham diperoleh sig $0,02<\alpha 0,05$ atau fhitung 0,793< ftabel 2,92 dengan demikian ho diterima dan h0 ditolak. Sehingga dapat disimpulkan bahwa Current Ratio, Debt To Equity Ratio dan Return On Equity Ratio secara simultan berpengaruh negatif terhadap Harga Saham.

Berdasarkan hasil penelitian beserta pengolahannya yang bersumber dari laporan keuangan yang terdaftar di Bursa Efek Indonesia (BEI) dan Annual 
Report pada tahunan 2016-2018, maka akan diuraikan hasil penelitian sesuai dengan permasalahn yang diajukan. Dalam pengujian secara parsial variabel current ratio tidak berpengaruh signifikan terhadap harga saham. sedangkan debt to equity ratio dan return on equity ratio berpengaruh negative terhadap harga saham.

\section{Pengaruh Current Ratio terhadap Harga Saham Perusahaan Subsektor Perkebunan Yang Terdaftar Di Bei Tahun 2016- 2018.}

Hasil pengujian untuk variabel likuiditas (CR) memiliki nilai signifikasi lebih besar dibandingkan level of significant yaitu sebesar $0,062>0,05$ dan nilai thitung sebesar $-0,093$ lebih kecil dibandingkan dari nilai ttabel sebesar 2,042. Yang artinya variabel Current Ratio tidak berpengaruh terhadap Harga Saham. Hal ini mungkin dikarenakan investor tidak melihat kemampuan suatu perusahaan dalam memenuhi kewajiban jangka pendeknya.

Hasil penelitian berbeda dengan penilitian sebelumnya yang dilakukan oleh Endah \& Rishi (2017) yang mendapatkan hasil penelitian bahwa Current Ratio berpengaruh signifikan terhadap Harga Saham.

Perbedaan hasil penelitian dipengaruhi oleh sektor dan waktu penelitian yang berbeda. Meskipun begitu, hasil penelitian ini sejalan dengan penilitan yang dilakukan oleh Aditya \& Teguh (2014) yang mendapatkan hasil bahwa Current Ratio tidak berpengaruh terhadap Harga Saham.

Pengaruh Debt to Equty Ratio Terhadap Harga Saham Perusahaan Subsektor Perkebunan Yang Terdaftar Di BEITahun 2016-2018.

$\begin{array}{ccr}\text { Hasil } & \text { pengujian } & \text { untuk } \\ \text { Solvabilitas } & \text { (DER) memiliki } & \text { nilai }\end{array}$ signifikasi lebih kecil dibandingkan level of significant yaitu sebesar 0,004 $<0,05$ dan nilai thitung sebesar - 1,287 lebih kecil dibandingkan dari nilai ttabel sebesar 2,042. Yang artinya variabel Debt To Equity Ratio berpengaruh negatif terhadap Harga Saham.

Hasil penelitian ini berbeda dengan penelitian yang dilakukan oleh Fendi \& Adeng (2017) yang mendapatkan hasil penelitian bahwa Debt To Equity Ratio tidak berpengaruh signifikan terhadap Harga Saham. meskipun begitu hasil penelitian ini sejalan dengan penelitian sebelumnya yang dilakukan oleh Meythi \& Linda (2011) yang mendapatkan hasil penelitian bahwa Debt To Equity Ratio berpengaruh terhadap Harga Saham

\section{Pengaruh Return On Equity Ratio terhadap Harga Saham Perusahaan Subsektor Perkebunan Yang Terdaftar di BEI Tahun 2016-2018.}

Profitabilitas (ROE) memiliki nilai signifikasi lebih kecil dibandingkan level of significant yaitu sebesar 0,009< 0,05 dan nilai thitung sebesar -584 lebih kecil dibandingkan dari nilai ttabel sebesar 2,042. Yang artinya variabel Return On Equity Ratio berpengaruh negatif terhadap Harga Saham. Dapat disimpulkan bahwa kenaikan laba berpengaruh terhadap keputusan investor dalam menanamkan modal.

Hasil penelitian ini sejalan dengan yan dilakukan oleh Aditya \& Teguh (2018) yang mendapatkan hasil penelitian bahwa Return On Equity Ratio berpengaruh signifikan terhadap Harga Saham. meskipun begitu hasil penelitian ini berbeda dengan penelitian sebelumnya yang dilakukan oleh Tita (2013) yang mendapatkan hasil penelitian bahwa Return On Equity Ratio tidak berpengaruh terhadap Harga Saham. 
Pengaruh Current Ratio, Debt to Equity Ratio Dan Return On Equity terhadap Harga Saham Perusahaan Subsektor Perkebunan Yang Terdaftar di BEI Tahun 2016-2018

Berdasarkan pengujian hipotesis yang telah dilakukan mengenai pengaruh Current Ratio, Debt To Equity Ratio dan Return On Equity Ratio terhadap Harga Saham secara simultan, fhitung lebih besar dari ftabel $(0,793<2,92)$, dan nilai signifikasi lebih kecil dibandingkan level of significant yaitu sebesar $0,02<0,05$. yang artinya Current Ratio, Debt To Equity Ratio dan Return On Equity Ratio secara simultan berpengaruh negatif terhadap Harga Saham.

Selain itu berdasarkan hasil koefisien determinasi didapatkan nilai sebesar 0,761, artinya Harga Saham pada perusahaan subsektor perkebunan di BEI tahun 2016-2018 dipengaruhi sebesar $76,1 \%$ oleh Current Ratio, Debt To Equity Ratio dan Return On Equity Ratio. sedangkan sisanya $22,9 \%$ dipengaruhi oleh variabel lain di luar penelitian.

Hasil penelitian ini sejalan dengan yang dilakukan oleh Tita (2013), Dimana hasil penelitian menunjukan bahwa secara simultan Current Ratio, Debt To Equity Ratio dan Return On Equity Ratio berpengaruh negatif terhadap Harga Saham.

\section{PENUTUP}

\section{Kesimpulan}

Berdasarkan hasil penelitian dan pembahasan yang telah dilakukan pada perusahaan Subsektor Perkebunan Yang Terdaftar Di Bursa Efek Indonesia Tahun 2016-2018, maka didapat kesimpulan sebagai berikut :

1. Secara parsial, Likuiditas yang diukur dengan Current Ratio tidak berpengaruh signifikan terhadap harga saham perusahaan subsektor perkebunan.
2. Solvabilitas yang diukur dengan Debt To Equity Ratio secara parsial berpengaruh signifikan terhadap Harga Saham perusahaan Subsektor Perkebunan.

3. Secara parsial, provitabilitas yang diukur dengan Return On Equity Ratio berpengaruh signifikan terhadap Harga Saham perusahaan Subsektor Perkebunan.

4. Current Ratio, Debt To Equity Ratio dan Return On Equity Ratio secara Simultan berpengaruh terhadap Harga Saham pada perusahaan Subsektor.

\section{Saran}

Bagi Perusahaan disarankan sebaiknya lebih mengefisiensikan tingkat biaya yang terjadi diperusahaan agar dapat menghasilkan laba yang diinginkan. Karena semakin besar tingkat laba bersih, maka daya Tarik investor semakin meningkat. Kemudian, perusahaan harus memperhatikan dan meningkatkan kinerja keuangan perusahaan. Agar dapat meningkatkan kepercayaan investor untuk berinvestasi pada perusahaan tersebut.

Bagi investor dalam mengambil keputusan investasi harus lebih memperhatikan kinerja keuangan perusahaan secara keseluruhan karna kinerja perusahaan yang baik adalah perusahaan yang mampu memperhatikan kinerja keuangan yang berkaitan dengan aktivitasnya.

Bagi peneliti selanjutnya, Untuk peneliti selanjutnya, dapat dilakukan penelitian dengan menambahkan variable-variabel lainnya. Dan juga bisa menambahkan periode penelitian dan tidak hanya berfokus pada perusahan subsektor perkebunan saja. Hal ini guna memperoleh hasil penelitian yang lebih signifikan serta menggunakan metode dan alat yang lebih lengkap dan akurat sehingga diperoleh kesimpulan yang lebih valid. 
DAFTAR PUSTAKA

Aditya, P, \& Teguh, E. (2014). Pengaruh Current Ratio, Debt To Equity Ratio, Return On Equity, Net Profit Margin dan Earning Per Hare Terhadap Harga Saham(Study Kasus Pada Perusahaan Manufaktur Yang Terdaftar di Bursa Efek Indonesia Periode 2008-2011). Jurnal Akuntansi, 2(1).

Endah, S, \& Rishi, S, S. (2017). Pengaruh CR, DER. ROE, TAT, dan EPS Terhadap Harga Saham Industri Farmasi di Bursa Efek Indonesia Tahun 2011-2015. Jurnal Online Insan Akuntan, 2(1).

Frendy, S, Parengkuan. T \& Marjam, M. (2015). Current Ratio, Debt To Equity Ratio, Return On Asset, Return On Equity Pengaruhnya Trhadap HARGA saham Pada Indeks LQ 45 Di Bursa Efek Indonesia Periode 2010-2014. Jurnal EMBA, 3(2).

Fendi, H, Ramadhani \& Adeng, P. (2017). Pengaruh Debt To Equity Ratio (DER), Return On Equity (ROE), dan Net Profit Margin (NPM) Terhadap Harga Saham Perusahaan Sektor Pertambangan yang terdaftar di Bursa Efek Indonesia Periode 2011-2015.
Indra, S., \& Pardinan. (2014). Pengaruh Current Ratio, Inventory Turnover, Time Interest Earned dan Return On Equity Terhadap Harga Saham Pada Perusahaan Manufaktur Sektor Barang Konsumsi Yang Terdaftar Di Bursa Efek Indonesia (BEI) Periode 2009-2012. Jurnal Nominal, 3(2).

Meythi, T.K, \& Linda, R. (2011). Pengaruh Likuiditas dan Profitabilitas Terhadap Harga Saham Perusahaan Manufaktur Yang Terdaftar Di Bursa Efek Indonesia (BEI). Jurnal Bisnis Manajemen dan Ekonomi, 10(2).

Tita, D. (2013). Pengaruh Current Ratio, Return On Equity dan Total Asset Trun Over Terhadap Devidend Payout Ratio dan Implikasi pada Harga Saham Perusahan LQ 45. Jurnal Bisnis dan Akuntansi, 15(1). 